\title{
Evaluation of serum levels and significance of soluble CD40 ligand in screening patients with hepatitis C virus-related hepatocellular carcinoma
}

\author{
S. M. Eltaher ${ }^{1}$, R. El-Gil ${ }^{2}$, N. Fouad ${ }^{2}$, R. Mitwali ${ }^{3}$ and H. El-Kholy ${ }^{4}$
}

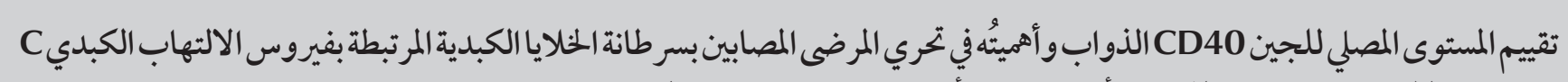

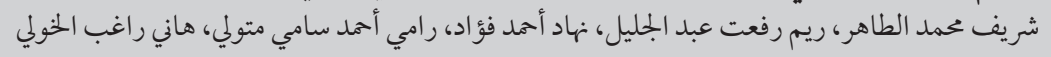

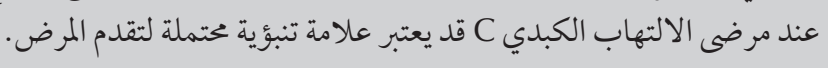

ABSTRACT The study's objective was to evaluate the clinical significance of SCD40L in HCV-associated hepatocellular carcinoma (HCV-HCC) patients. Sera concentration of circulating sCD40L and IL-10 were assayed using ELISA in 30 HCVpositive patients with HCC, $30 \mathrm{HCV}$-positive patients with liver cirrhosis and 30 age-matched healthy volunteers with negative anti-HCV-Ab as a control group. Serum SCD40Lshowed statistically-significant high levels in HCV-HCC patients compared to HCV-cirrhotic patients and normal controls $(P<0.001)$. Serum SCD40L had higher diagnostic value in HCC patients compared with serum AFP. High sensitivity and specificity of sCD40L was observed compared to AFP $(90 \%$, $86.7 \%$ and $83 \%$ and $80 \%$ respectively). Significant positive correlation was detected between serum SCD $40 \mathrm{~L}$ and IL-10( $\mathrm{r}=$ $0.85 P<0.001)$, AFP $(r=0.62 P<0.05)$ and tumour staging $(r=0.5 P<0.05)$. The study concluded that SCD $40 \mathrm{~L}$ is a valuable diagnostic tool in early diagnosis and screening for HCV and HCC as well as routine follow up of HCV cirrhosis patients. Assessment of serum IL-10 levels in HCV patients may provide a possible predictive marker for disease progression.

\section{Évaluation des concentrations sériques et du rôle du ligand de CD40 soluble dans le dépistage des patients atteints d'un} carcinome hépatocellulaire lié au virus de l'hépatite $\mathrm{C}$

RÉSUMÉ L'objectif de l'étude était d'évaler l'importance clinique du ligand de CD40 soluble (sCD40L) chez des patients atteints d'un carcinome hépatocellulaire (CHC) associé au virus de l'hépatite C (VHC). Les concentrations sériques de sCD40L circulant et d'interleukine 10 circulante ont été analysées à l'aide de la méthode immuno-enzymatique chez 30 patients positifs pour le VHC avec un $\mathrm{CHC}$, chez 30 patients patients positifs pour le VHC avec une cirrhose du foie, et chez 30 volontaires d'âge correspondant en bonne santé avec des anticorps anti-VHC négatifs servant de groupe témoin. Les concentrations sériques de sCD40L ont montré des niveaux statistiquement élevés chez les patients atteints d'un CHC associé au VHC par rapport aux concentrations sériques d'AFP. Les concentrations sériques de sCD40L avaient une valeur diagnostique plus élevée chez les patients atteints d'un CHC que les concentrations sériques d'AFP. Une sensibilité élevée et la spécificité du SCD40L ont été observées par rapport à I'AFP (90\%, 86,7 \% et $83 \%$ et $80 \%$ respectivement). Une corrélation positive significative a été détectée entre les concentrations sériques de SCD40L et d'IL-10 $(r=0,85 p<0,001)$, I'AFP $(r=0,62 P<0,05)$ et le stade de la tumeur $(r=0,5 p<0,05)$. L'étude a conclu que le $\mathrm{s} C D 40 \mathrm{~L}$ est un outil précieux pour le diagnostic et le dépistage précoces de l'infection à VHC et du CHC, ainsi que pour le suivi de routine des patients cirrhotiques positifs pour le VHC. L'évaluation des concentrations sériques d'IL-10 chez les patients positifs pour le VHC pourrait fournir un possible marqueur prédictif pour l'évolution de la maladie.

'Department of Public Health and Community Medicine (Correspondence to: S.M. Eltaher: sherefmoh@gmail.com; sherif.abdelmonem@fmed.bu.edu. eg). ${ }^{2}$ Medical Microbiology and Immunology Department. ${ }^{3}$ Internal Medicine Department. ${ }^{4}$ Hepatology and Gastroenterology Department, Faculty of Medicine, Benha University, Benha, Egypt.

Received: 25/03/15; accepted: 06/04/16 


\section{Introduction}

Primary liver cancer is the third leading cause of cancer-related mortality and the sixth most common cancer worldwide with $\sim 750000$ new cases every year (1). Hepatocellular carcinoma (HCC) accounts for $\sim 90 \%$ of primary liver cancers and remains the leading cause of death among patients with cirrhosis (2). Three-quarters of all the cases worldwide are attributed to chronic infection by hepatitis $\mathrm{B}$ virus (HBV) and hepatitis $\mathrm{C}$ virus (HCV) (3). The aetiology of $\mathrm{HCC}$ in Egypt indicates a higher prevalence of HCV than HBV (3). The risk of developing HCC in HCV-positive patients increases dramatically with severity of inflammation. This is most probably due to the influence of the inflammation, predominantly mediated by cytokines, on supporting the tumour microenvironment (4).

The poor prognosis of HCC is mostly linked to late diagnosis because few treatment strategies can be implemented in patients with advanced disease (4). Surgical resection is the only effective treatment; however, only a few patients are candidates for surgery. The ability to detect early HCC would increase the availability of surgery and improve patient survival (4).

Although many candidate molecular markers of HCC have been identified, such as $\boldsymbol{\alpha}$-fetoprotein (AFP), glypican-3 and squamous cell carcinoma antigen-1, markers with the necessary sensitivity and specificity for early detection are still lacking. The most widely utilized blood-based biomarker is AFP, which is markedly elevated in patients with cirrhosis and/or exacerbated non-HCC chronic hepatitis (5). Moreover, there is a high false-negative rate of AFP in HCC patients with small or early-stage tumours $(6,7)$. Thus, AFP still lacks adequate sensitivity and specificity for effective surveillance of HCC (5-7). Glypican-3 and squamous cell carcinoma antigen- 1 are elevated in many other tumours, so their role is still controversial.

The most sensitive diagnosis of HCC currently requires invasive imaging procedures such as endoscopic ultrasonography, which can lead to hepatic injury, and the accuracy of these procedures is highly operator dependent. Therefore, identification of reliable new markers with better performance for early detection of HCC would have a major impact on treatment outcome (4).

In the current study, we investigated the utility of soluble CD40 ligand $(\mathrm{sCD} 40 \mathrm{~L})$ as a reliable marker for early detection of HCC and other neoplastic lesions in the liver. CD40L (also known as gp39 or CD154) is a trimeric, transmembrane protein of the tumour necrosis factor family that was originally identified on cells of the imt mune system (8). It was first identified in activated CD4+ $\mathrm{T}$ cells, mast cells, polymorphonuclear granulocytes, and natural killer cells (8). Subsequent studt ies revealed functional CD40L expresv sion in a wide variety of cells, including endothelial cells, smooth muscle cells, macrophages and activated platelets $(9,10)$. Membrane-bound CD40L is potentially cleaved into $\mathrm{SCD} 40 \mathrm{~L}$, which has cytokine-like activity and is released into the circulation $(11,12)$. Both membrane-bound CD40L and circulating sCD40L interact with CD40 protein that is expressed on vascular cells, resulting in several inflammatory and prothrombotic responses (13).

The significant platelet activation and inadequate $\mathrm{T}$-cell reactivity in cancer patients indicates the greater likelihood of releasing or cleaving SCD40L from the platelets rather than $\mathrm{T}$ cells (14). Therefore, sCD40L can affect cancer development and progression by inducing thrombotic reactions and releasing angiogenesis-associated cytokines $(14,15)$.

Widespread expression of CD40 in humans implies that its ligand has an important role in cancer pathogenesis (16): inhibiting apoptosis; facilitating metastases (17); increasing epithelial cell proliferation, motility and invasion (18); and producing cytokines, such as interleukin (IL)-10, that modulate the anti-tumour response of $\mathrm{T}$ lymphocytes (13). Increased levels of IL-10 have been found in the plasma of patients with different histotypes of solid and haematopoietic tumours $(19,20)$. IL10 has been evaluated as a marker for HCC, however, it has not yet been validated for clinical use (21).

In the current study, we evaluated the clinical significance of $\mathrm{SCD} 40 \mathrm{~L}$ in patients with $\mathrm{HCV}$-associated HCC compared with patients with liver cirrhosis as well as normal healthy controls. We also explored serum level of sCD40L as a novel potential marker for diagnosis and screening of HCC and validated it against the traditional marker AFP.

\section{Methods}

\section{Patients}

Sixty HCV-positive patients either attended or were admitted to the Department of Hepatology and Gastroenterology or Internal Medicine, Benha University Hospital, Egypt from October 2014 to March 2015. All procedures were performed in accordance with institutional guidelines using protocols approved by Benha Faculty of Medicine Patient Care and Ethics Committee. Written informed consent was obtained from patients and controls.

The study population was divided as follows: Group I, $30 \mathrm{HCV}$-positive patients with HCC aged 32-64 years; Group II, $30 \mathrm{HCV}$-positive patients with liver cirrhosis aged 34-58 years; and Group III, 30 healthy volunteers, negative for HCV antibody, aged 19-48 years old as a control group. Consideration of the socioeconomics of the patient groups was beyond the scope of this study. HCV-positive 
patients received supportive treatment alone without any anti-HCV medication before or during the study.

We used triphasic computed tomography, and/or magnetic resonance imaging to detect characteristic focal lesions of HCC, with or without elevated AFP. Biopsied tumours were staged using the Okuda staging system for $\operatorname{HCC}(22)$.

\section{Serum samples}

All patients and controls were subjected to thorough clinical examinations before 5-mL blood samples were collected by sterile venipuncture and allowed to clot. Serum samples were separated, aliquoted and stored at -20 ${ }^{\circ} \mathrm{C}$. Comprehensive laboratory investigations were conducted including: serum alanine aminotransferase (ALT), aspartate aminotransferase (AST), alkaline phosphatase (ALP), bilirubin, albumin, hepatitis $B$ surface antigen and
HCV antibody. AFP levels (0.3-1000 $\mathrm{ng} / \mathrm{mL}$ ) were assessed by Axsym using microparticle enzyme immunoassay (MEIA) technology.

\section{Serum sCD40L and IL-10 assays}

Circulating sCD40L and IL-10 were assessed using a commercial ELISA (Quantikine, R\&D Systems, Minneapolis, MN, USA). A quantitative sandwich enzyme immunoassay technique using a polyclonal antibody specific for CD40L or IL-10 was utilized with a minimum detection limit of $4.2 \mathrm{pg} / \mathrm{mL}$ for CD40L and $3.9 \mathrm{pg} / \mathrm{mL}$ for IL-10.

\section{Statistical analysis}

The data were tabulated, coded and analysed using SPSS version 20. Qualis tative data were presented as numbers and percentages, and quantitative data as mean and standard deviation. Analysis of variance (ANOVA) was used to compare more than two groups of numerical data; post hoc analysis was done using Dunnett's test; intergroup comparison of categorical data was performed using the $\chi^{2}$ test; and Pearson and Spearman rank correlation coefficients $(r)$ were used to correlate different parameters. Receiver operatt ing characteristic curves were used to evaluate the diagnostic power of the different diagnostic tests. $P<0.05$ was considered statistically significant.

\section{Results}

\section{Clinical and demographic data}

Clinical and demographic data are presented in Table 1. There was no significant difference in gender between patients and controls $(P>0.05)$. Age was significantly higher in Groups I and II compared to Group III $(P<0.001)$. There was no significant difference

\begin{tabular}{|c|c|c|c|c|}
\hline Variable & $\begin{array}{l}\text { Group I } \\
(n=30)\end{array}$ & $\begin{array}{c}\text { Group II } \\
(n=30)\end{array}$ & $\begin{array}{c}\text { Group III } \\
(n=30)\end{array}$ & $P$ \\
\hline Age (years) ${ }^{a}$ & $59(8.4)$ & $53(7.5)$ & $30(7.9)$ & $<0.001$ \\
\hline Gender (female/male) & $18 / 12$ & $15 / 15$ & $10 / 20$ & $>0.05$ \\
\hline \multicolumn{5}{|l|}{ Clinical picture } \\
\hline Hepatomegaly & $6(20 \%)$ & $2(6.7 \%)$ & - & $>0.05$ \\
\hline Splenomegaly & $30(100 \%)$ & $25(83.3 \%)$ & - & $>0.05$ \\
\hline Ascites & $20(66.7 \%)$ & $18(60 \%)$ & - & $>0.05$ \\
\hline \multicolumn{5}{|l|}{ Serum levels ${ }^{a}$} \\
\hline Albumin (mg/dL) & $2.73(0.42)$ & $2.807(0.36)$ & $7.23(0.06)$ & $<0.001$ \\
\hline $\operatorname{ALT}(\mathrm{U} / \mathrm{L})$ & 55.7 (19.9) & $45.4(11.7)$ & $24.8(3.6)$ & $<0.001$ \\
\hline $\operatorname{AST}(\mathrm{U} / \mathrm{L})$ & $60(18.3)$ & $48.2(13.2)$ & $20.4(3.4)$ & $<0.001$ \\
\hline $\operatorname{ALP}(U / L)$ & $246.8(86) .4$ & $213.6(56.2)$ & $67(20.8)$ & $<0.001$ \\
\hline Total bilirubin (mg/dL) & $3.68(0.72)$ & $1.71(0.94)$ & $0.9(0.3)$ & $<0.001$ \\
\hline \multicolumn{5}{|l|}{ Tumour number } \\
\hline Single/multiple & $16 / 14$ & - & - & - \\
\hline \multicolumn{5}{|l|}{ Tumour stage } \\
\hline Stage I & $10(33.3 \%)$ & - & - & - \\
\hline Stage II & $14(46.7 \%)$ & - & - & - \\
\hline Stage III & $6(20 \%)$ & - & - & - \\
\hline \multicolumn{5}{|l|}{ Tumour size } \\
\hline$<3 \mathrm{~cm} />3 \mathrm{~cm}$ & $22 / 8$ & - & - & - \\
\hline
\end{tabular}

${ }^{a}$ Data expressed as mean (standard deviation).

$A L T=$ alanine aminotransferase $; A L P=$ alkaline phosphatase $; A S T=$ aspartate aminotransferase. 
between Groups I and II for hepatomegaly, splenomegaly and ascites (all $P$ $>0.05)$. Among patients with HCC, 16 (53.3\%) had a single mass with defined borders. Tumour stage I, II and III was found in 10 (33.3\%), 14 (46.7\%) and 6 (20\%) patients with HCC, respectively. Tumour size was $<3 \mathrm{~cm}$ in $22(73.3 \%)$ and $>3 \mathrm{~cm}$ in $8(26.7 \%)$ patients.

\section{Laboratory results}

ALT, AST, ALP and total bilirubin were significantly higher in Group I than in Groups II and III (all $P<0.001$ ) (Table 1). Serum albumin was significantly higher in Group III than Groups I and II $(P<0.001)$.

\section{Serum sCD40L, IL-10 and AFP levels}

Serum sCD40L, IL-10 and AFP levels are presented in Table 2. Serum sCD40 L level was significantly higher in
Group I than Groups II and III (one-way ANOVA, $P<0.001)$. Serum sCD40L level was also significantly higher in Group II than Group III (post hoc test, $P<0.001$ ). Similarly, serum IL-10 level was significantly higher in Group I than Groups II and III (one-way ANOVA, $P$ $<0.001)$. Also, it was higher in Group II than Group III (post hoc test, $P<$ 0.001). Similar findings were observed for serum level of AFP.

To compare the diagnostic accuracy of serum $\mathrm{SCD} 40 \mathrm{~L}$ and $\mathrm{AFP}$ for HCC, receiver operating characteristic curves were generated and area under the curve (AUC) was calculated. Serum sCD40L exhibited superior diagnostic potential for HCC in comparison with serum AFP. AFP level had an AUC value of 0.860 with $83 \%$ sensitivity and $80 \%$ specificity at a cut-off of $273 \mathrm{ng} /$ $\mathrm{mL}$ (Figure 1). In contrast, $\mathrm{sCD} 40 \mathrm{~L}$ level had a significantly higher AUC value of 0.930 with $90 \%$ sensitivity and $86.7 \%$ specificity at a cut-off of 7305.5 $\mathrm{pg} / \mathrm{mL}$. Markedly high specificity and sensitivity, $\sim 96.7 \%$ for both, were only possible when the two markers were combined, with an AUC value as high as 0.960 .

\section{Correlation between sCD40L level and different parameters}

sCD40L showed a significantly positive correlation with IL-10 $(r=0.85 ; P<$ $0.001)$, AFP $(r=0.62 ; P<0.05)$ and tumour stage $(r=0.5 ; P<0.05)$ (Table 3$)$. No significant positive correlation was established between serum sCD40L level and tumour size, age, albumin, bilirubin, AST and ALT (Table 3, Figure 2 ). The correlations were calculated among all the groups for all variables, except for tumour size and stage, which were calculated for Group I only.
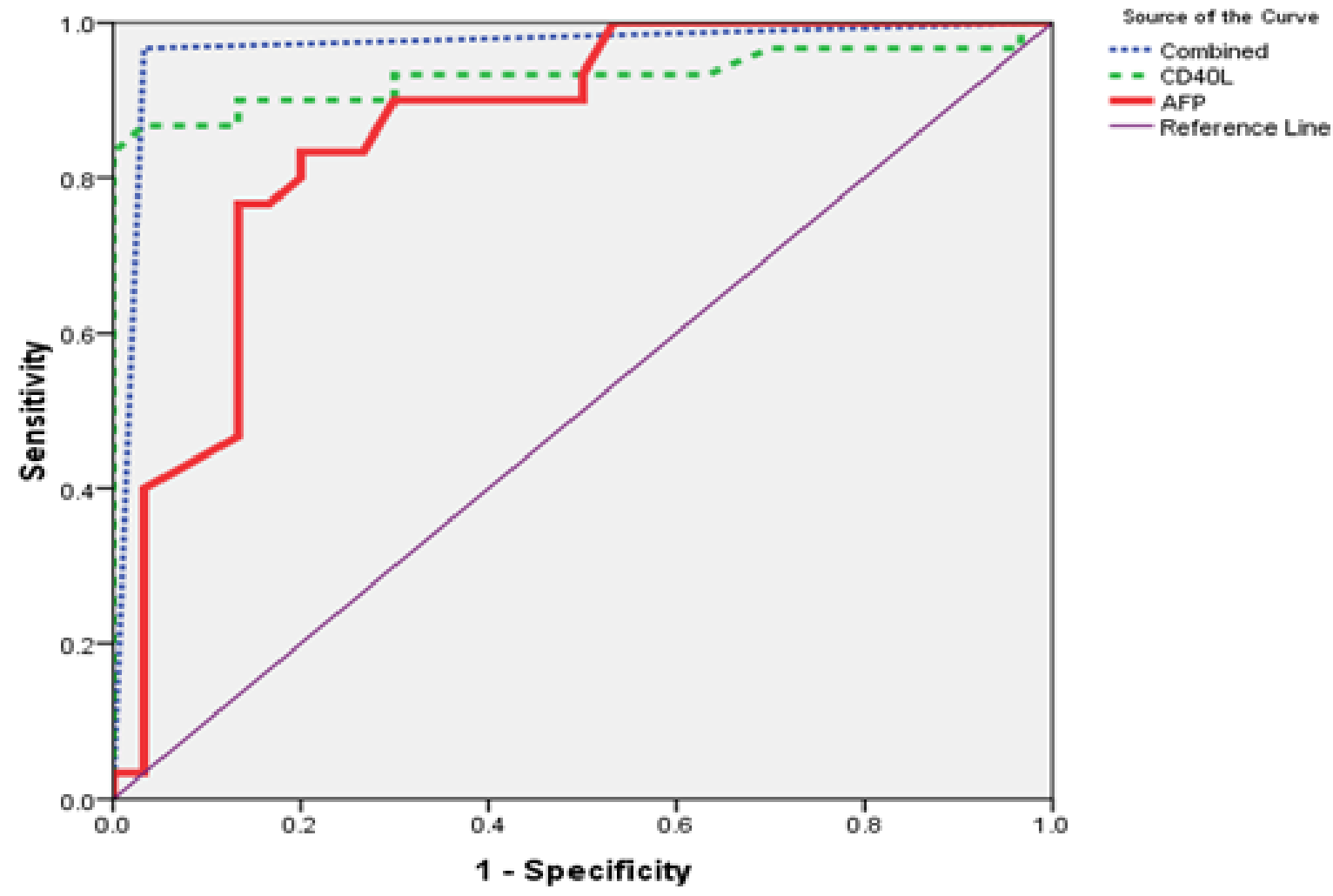

Figure 1 Diagnostic accuracy of $\mathrm{SCD} 40 \mathrm{~L}$ and AFP for hepatitis-C-virus-associated hepatocellular carcinoma. AUC was 0.860 and 0.930 for AFP and sCD40L, respectively. For the two combined markers AUC was 0.960. AFP $=\alpha$-fetoprotein; $A U C=$ area under the curve; $s \mathrm{CD} 40 \mathrm{~L}=$ soluble $\mathrm{CD} 40$ ligand. 




Figure 2 Correlation between SCD40L and IL-10. There was a positive correlation between serum SCD40L and IL-10 among the study groups. IL-10 = interleukin-10; sCD40L = soluble CD40 ligand.

\section{Discussion}

Several studies have suggested the essential role of binding sCD40L to CD40 protein in tumour development, propagation, tumour microenvironmental and metastasis $(23,24)$. However, little is known about the behaviour of platelet-derived $\mathrm{sCD} 40 \mathrm{~L}$ after becoming detached from the cell surface and its downstream effects in cancer patients.

To explore the potential role of serum $\mathrm{SCD} 40 \mathrm{~L}$ as a diagnostic and prognostic marker for HCC, we evaluated sCD40L levels in patients with HCVpositive HCC. To validate its role, we compared HCV-positive patients with liver cirrhosis and a control group of $\mathrm{HCV}$-negative healthy volunteers with intact liver margins and no evidence of any cirrhotic cells. To the best of our knowledge, this is the first study to validate serum $\mathrm{SCD} 40 \mathrm{~L}$ as a potential diagnostic and prognostic marker for HCC.

The markedly elevated level of sCD40L in HCV-HCC patients compared to healthy individuals indicates the potential of using serum $\triangle C D 40 \mathrm{~L}$ as a marker for early detection of HCC. In addition, it underlines the presumed role of sCD40L in many molecular events including carcinogenesis, angiogenesis and immunosuppression (25). Similarly, the increase in serum $\mathrm{SCD} 40 \mathrm{~L}$ in $\mathrm{HCV}$-associated HCC relative to its level in HCV-positive patients with liver cirrhosis reflects the direct correlation between elevated serum $\mathrm{SCD} 40 \mathrm{~L}$ and progression of HCC. The increase in serum sCD40L in HCV-positive patients with liver cirrhosis compared with the HCV-negative control group indicates the potential of serum $\mathrm{sCD} 40 \mathrm{~L}$ as a molecular marker for minimally invasive, early detection of HCC. The main advantage of this technique is the ability to detect early changes in $\mathrm{SCD} 40$ in contrast to the traditional late morphological remodelling.

\begin{tabular}{lcccc}
\hline \multicolumn{1}{l}{ Table 2 Serum levels of sCD40L, AFP and IL-10 } & & & \\
Variable & $\begin{array}{c}\text { Group I } \\
(\boldsymbol{n}=30)\end{array}$ & $\begin{array}{c}\text { Group II } \\
(\boldsymbol{n}=30)\end{array}$ & $\begin{array}{c}\text { Group III } \\
(\boldsymbol{n}=30)\end{array}$ & $\boldsymbol{P}$ \\
Serum sCD40L $(\mathrm{pg} / \mathrm{mL})$ & $9462(2385)^{\mathrm{b}}$ & $6956(1754)^{\mathrm{a}}$ & $3280(938)^{\mathrm{a}, \mathrm{b}}$ & $<0.001$ \\
Serum AFP $(\mathrm{ng} / \mathrm{mL})$ & $459.6(54.9)^{\mathrm{b}}$ & $7.8(2.2)^{\mathrm{a}}$ & $3.47(1.58)^{\mathrm{a}, \mathrm{b}}$ & $<0.001$ \\
Serum IL-10 $(\mathrm{pg} / \mathrm{mL})$ & $13.86(3.58)^{\mathrm{b}}$ & $8.63(2.57)^{\mathrm{a}}$ & $4.37(1.53)^{\mathrm{a}, \mathrm{b}}$ & $<0.001$ \\
\hline
\end{tabular}

${ }^{a}$ Significantly different from Group I (HCV-related HCC).

${ }^{b}$ Significantly different Group II (HCV-related cirrhosis).

AFP = a-fetoprotein; $H C C=$ hepatocellular carcinoma; $H C V=$ hepatitis $C$ virus; $I L-10=$ interleukin-10; $s C D 40 L=$ soluble CD40 ligand. 


\begin{tabular}{lcc}
\hline Table 3 Correlation between sCD40L and different variables & \\
\hline Variable & $\boldsymbol{r}$ & $\boldsymbol{P}$ \\
IL-10 $^{\mathrm{a}}$ & 0.85 & $<0.001$ \\
AFP $^{\mathrm{a}}$ & 0.62 & $<0.05$ \\
Tumour stage $^{\mathrm{b}}$ & 0.5 & $<0.05$ \\
Tumour size $^{\mathrm{b}}$ & -0.1 & $>0.05$ \\
Age $^{\mathrm{a}}$ & 0.09 & $>0.05$ \\
Albumin $^{\mathrm{a}}$ & 0.13 & $>0.05$ \\
Bilirubin $^{\mathrm{a}}$ & 0.16 & $>0.05$ \\
AST $^{\mathrm{a}}$ & 0.14 & $>0.05$ \\
ALT $^{\mathrm{a}}$ & 0.13 & $>0.05$ \\
\hline
\end{tabular}

${ }^{a}$ Pearson correlation.

${ }^{b}$ Spearman rank correlation.

$A F P=a$-fetoprotein $; A L T=$ alanine aminotransferase $; A S T=$ aspartate aminotransferase $; l L-10=$ interleukin -10 sCD4OL = soluble CD40 ligand.

As in previous studies, serum AFP showed a less significant increase in patients with HCV-associated HCC compared with $\mathrm{HCV}$-positive patients with cirrhosis and the HCV-negative control group $(26,27)$.

The superior selectivity of $\mathrm{sCD} 40 \mathrm{~L}$ as a marker was demonstrated by the AUC value of 0.930 , compared to 0.860 for AFP. This not only reflects the superiority of $\mathrm{sCD} 40 \mathrm{~L}$ in detecting $\mathrm{HCC}$, but more importantly, in differentiating HCV-positive cancer patients from $\mathrm{HCV}$-positive cancer-free patients. This attribute makes sCD40L a marker of choice in cases in which traditionally used serum AFP cannot distinguish between cancer patients and cancer-free individuals. For instance, it has been reported that some patients with HCC present without any elevation of serum AFP level (28). In contrast, cancer-free patients with liver cirrhosis show elevated serum AFP level regardless of the absence of any clinical and molecular evidence of cancer cells. This allows serum $\mathrm{SCD} 40 \mathrm{~L}$ to overcome the limitations of AFP as a selective biomarker in individuals in whom it is not possible to discern adequately HCC.

Our results suggest that $\mathrm{SCD} 40 \mathrm{~L}$ and AFP should be measured simultaneously to improve diagnostic accuracy, especially in the early stage of HCC or in cases with small tumour size, and with a significant increase in AUC of 0.960 .

The positive correlation between serum $\mathrm{SCD} 40 \mathrm{~L}$ and tumour staging in patients with $\mathrm{HCV}$-positive HCC reflects the potential of using serum sCD40L as a noninvasive tool for determining HCC prognosis and curability. However, its reliability as marker that stands alone without the need for liver biopsy needs to be further investigated.

For some individuals, it can take up to 40 years for chronic hepatitis $\mathrm{C}$ to develop into cirrhosis (29). This may depend on the underlying cause and other factors, including patient response rate to disease progression and decline in immune function with ageing. This long-term development of cirrhosis may explain the older age of patients in Groups I and II relative to individuals in the control Group III.

The ALT and AST levels differed greatly among all three groups and it was not possible to establish any correlation with sCD40L level. The observed results might have been due to the modest elevation in the enzyme levels, usually less than 2-3 times the normal range, observed in patients with acuteover-chronic cirrhosis. Some patients even showed a dramatic decrease in aminotransferase level, with laboratory evidence of hepatic failure.
It is evident that the metabolic functions of the liver decline dramatically and directly with cirrhosis development. Albumin is extensively synthesized in the liver, therefore, major decreases in its levels are predictable in patients with liver disease, especially with acute-over chronic cirrhosis. This could explain the lack of a significant correlation between serum sCD40L and albumin, mainly in patients in Groups I and II.

The lack of correlation between serum sCD40L and bilirubin resulted from variation in its levels from normal in cases of compensated cirrhosis and some cases of HCC to elevated levels as cirrhosis progressed.

Significantly elevated levels of serum IL-10 were observed in patients with $\mathrm{HCV}$-positive HCC and HCV-positive cirrhosis compared with cancer-free individuals. Similar significant elevation of serum IL-10 has also been reported in patients with different types of chronic hepatitis $C$ and various stages of cirrhosis (30,31). Level of IL-10 was mostly prominent in patients with severe hepatic lesions and development of HCC, which contributed to immunosuppression by inhibiting antigen presentation, cytokine production, macrophage activation and antigenspecific T-cell proliferation. All these factors help tumour cells to escape host immune surveillance and potentiate them to metastasize.

In this study, significant elevation of serum IL-10 level in patients with $\mathrm{HCV}$-positive HCC compared to HCV-positive cirrhosis supports the direct correlation between IL-10 serum level and clinical outcome. Therefore, serum IL-10 may serve as a predictive marker for HCC progression in HCVpositive patients. It has been suggested that IL-10 level serves as complementary tumour marker and contributes to differential diagnosis of HCC (31). In addition, it is reported that IL-10 is produced vigorously by some tumour cells $(32,33)$. High circulating and local levels of IL-10 might allow tumour cells 
to elude host defence mechanisms and affect the metastatic potential of the tumour. The positive correlation between IL- 10 and $\mathrm{SCD} 40 \mathrm{~L}$ in all the groups in our study suggests that the higher level of SCD40L seen in HCC patients has an immunosuppressive effect through induction of IL-10. This is in accordance with previous results indicating that sCD40L induces expansion of regulatory $\mathrm{T}$ cells and production of IL-10, which can affect both HCC development and metastasis $(25,34)$.

In conclusion, we detected significantly elevated levels of SCD40L in patients with $\mathrm{HCV}$-positive HCC. We provide fundamental clinical evidence of the utility of $\mathrm{SCD} 40 \mathrm{~L}$ as a diagnostic tool with the potential to replace AFP in everyday diagnosis and screening of HCC and routine follow-up of patients with HCV cirrhosis. Our data indicate the potential of using serum IL-10 levels in $\mathrm{HCV}$-positive patients as a predictive marker for disease progression. The full utility of this approach needs further studies with larger numbers of patients with age- and sex-matched controls. We also need prolonged follow-up of patients with HCC and cirrhosis to clarify the role of $\mathrm{sCD} 40 \mathrm{~L}$ in the early diagnosis and improvement of prognosis of HCC

Funding: None.

Conflict of interest: None declared..

\section{References}

1. Ferlay J, Shin HR, Bray F, Forman D, Mathers C, Parkin DM. Estimates of worldwide burden of cancer in 2008. GLOBOCAN 2008. Int J Cancer. 2010;127(12):2893-917.

2. Ioannou GN, Splan MF, Weiss NS, McDonald GB, Beretta L, Lee SP. Incidence and predictors of hepatocellular carcinoma in patients with cirrhosis. Clin Gastroenterol Hepatol. 2007 Aug;5(8):938-45, 945.el-4. PMID:17509946

3. Lehman EM, Wilson ML. Epidemiology of hepatitis viruses among hepatocellular carcinoma cases and healthy people in Egypt: a systemic review and meta-analysis. Int J Cancer. 2009;124(3):690-7. PMID:18973270

4. Llovet JM, Burroughs A, Bruix J. Hepatocellular carcinoma. Lancet. 2003;362(9399):1907-17. PMID:14667750

5. Bae JS, Park SJ, Park KB, Paik SY, Ryu JK, Choi CK, et al. Acute exacerbation of hepatitis in liver cirrhosis with very high levels of alpha-fetoprotein but no occurrence of hepatocellular carcinoma. Korean J Intern Med. 2005 Mar;20(1):80-5. PMID:15906959

6. Toyoda H, Kumada T, Tada T. Highly sensitive Lens culinaris agglutinin-reactive $\boldsymbol{\alpha}$-fetoprotein: a new tool for the management of hepatocellular carcinoma. Oncology. 2011;81 Suppl 1:61-5. PMID:22212938

7. Matsuda $\mathrm{M}$, Asakawa $\mathrm{M}$, Amemiya $\mathrm{H}$, Fujii H. Lens culinaris agglutinin-reactive fraction of AFP is a useful prognostic biomarker for survival after repeat hepatic resection for HCC. J Gastroenterol Hepatol. 2011 Apr;26(4):731-8. PMID:21155886

8. Andre P, Nannizzi-Alaimo L, Prasad SK, Phillips DR. Plateletderived CD40L: the switch-hitting player of cardiovascular disease. Circulation. 2002;106(8):896-9. PMID:12186789

9. Anand SX, Viles-Gonzalez JF, Badimon JJ, Cavusoglu E, Marmur JD. Membrane-associated CD40L and SCD40L in atherothrombotic disease. Thromb Haemostat. 2003;90(3):377-84. PMID:12958605

10. Henn V, Slupsky JR, Gräfe M, Anagnostopoulos I, Förster R, Müller-Berghaus G, et al. CD40 ligand on activated platelets triggers an inflammatory reaction of endothelial cells. Nature. 1998 Feb 5;391(6667):591-4. PMID:9468137

11. Aukrust P, Müller F, Ueland T, Berget T, Aaser E, Brunsvig A, et al. Enhanced levels of soluble and membrane-bound CD40 ligand in patients with unstable angina. Possible reflection of T lymphocyte and platelet involvement in the pathogenesis of acute coronary syndromes. Circulation. 1999 Aug 10;100(6):614-20. PMID:10441098

12. Aloui $C$, Prigent $A$, Sut $C$, Tariket $S$, Hamzeh-Cognasse $H$, Pozzetto B, et al. The signaling role of CD40 ligand in platelet biology and in platelet component transfusion. Int J Mol Sci. 2014 Dec;15(12):22342-64. PMID:25479079

13. Lindmark E, Tenno T, Siegbahn A. Role of platelet P-selectin and CD40 ligand in the induction of monocytic tissue factor expression. Arterioscler Thromb Vasc Biol. 2000;20(10):23228. PMID:11031222

14. Sciulli MG, Filabozzi P, Tacconelli S, Padovano R, Ricciotti E, Capone ML, et al. Platelet activation in patients with colorectal cancer. Prostaglandins Leukot Essent Fatty Acids. 2005 Feb;72(2):79-83. PMID:15626589

15. Osada J, Rusak M, Kamocki Z, Dabrowska MI, Kedra B. Platelet activation in patients with advanced gastric cancer. Neoplasma. 2010;57(2):145-50. PMID:20099978

16. Sabel MS, Yamada M, Kawaguchi Y, Chen FA, Takita H, Bankert RB. CD40 expression on human lung cancer correlates with metastatic spread. Cancer Immunol Immunother. 2000 May;49(2):101-8. PMID:10823420

17. Yamaguchi $\mathrm{H}$, Tanaka F, Sadanaga $\mathrm{N}$, Ohta $\mathrm{M}$, Inoue $\mathrm{H}$, Mori M. Stimulation of CD40 inhibits Fas- or chemotherapymediated apoptosis and increases cell motility in human gastric carcinoma cells. Int J Oncol. 2003 Dec;23(6):1697-702. PMID:14612943

18. Baxendale AJ, Dawson CW, Stewart SE, Mudaliar V, Reynolds G, Gordon J, et al. Constitutive activation of the CD40 pathway promotes cell transformation and neoplastic growth. Oncogene. 2005 Nov 24;24(53):7913-23. PMID:16091748

19. Fortis C, Foppoli M, Gianotti L, Galli L, Citterio G, Consogno G, et al. Increased interleukin-10 serum levels in patients with solid tumours. Cancer Lett. 1996 Jun 24;104(1):1-5. PMID:8640735

20. Blay JY, Burdin N, Rousset F, Lenoir G, Biron P, Philip T, et al. Serum interleukin-10 in non-Hodgkin's lymphoma: a prognostic factor. Blood. 1993 Oct 1;82(7):2169-74. PMID:8400266

21. Hsia CY, Huo TI, Chiang SY, Lu MF, Sun CL, Wu JC, et al. Evaluation of interleukin-6, interleukin-10 and human hepatocyte growth factor as tumor markers for hepatocellular carcinoma. Eur J Surg Oncol. 2007 Mar;33(2):208-12. PMID:17140760

22. Okuda K, Ohtsuki T, Obata H, Tomimatsu M, Okazaki N, Hasegawa $\mathrm{H}$, et al. Natural history of hepatocellular carcinoma and prognosis in relation to treatment. Study of 850 patients. Cancer. 1985 Aug 15;56(4):918-28. PMID:2990661

23. El-Serag HB. Hepatocellular carcinoma. N Engl J Med. 2011 Sep 22;365(12):1118-27. PMID:21992124

24. Amirkhosravi A, Amaya M, Desai H, Francis JL. Platelet-CD40 ligand interaction with melanoma cell and monocyte CD40 
enhances cellular procoagulant activity. Blood Coagul Fibrinolysis. 2002;13(6):505-12. PMID:12192302

25. Huang J, Jochems C, Talaie T, Anderson A, Jales A, Tsang $\mathrm{KY}$, et al. Elevated serum soluble CD40 ligand in cancer patients may play an immunosuppressive role. Blood. 2012 Oct 11;120(15):3030-8. PMID:22932804

26. El-Shenawy S, El Sabawi M, Sheble N, El-Raof MA, Allam MM, Fath Allah SK. Diagnostic role of serum glypican-3 as a tumor marker for hepatocellular carcinoma. Nat Sci. 2012;10(4):32-8. http://www.sciencepub.net/nature/ ns1004/006_8707ns1004_32_38.pdf

27. Gomaa A, Hendy O, Abou Raia GY, Attia H, El ezaway HM, Nafie E, et al. The diagnostic value of peripheral blood glypican-3 in patients with hepatocellular carcinoma. World J Med Sci. 2012;7(2):105-12. http://www.idosi.org/wjms/7(2)12/11. pdf

28. Daniele B, Bencivenga A, Megna AS, Tinessa V. Alpha-fetoprotein and ultrasonography screening for hepatocellular carcinoma. Gastroenterology. 2004 Nov;127(5) Suppl 1:S108-12. PMID:15508073

29. Tsochatzis EA, Bosch J, Burroughs AK. Liver cirrhosis. Lancet. 2014 May 17;383(9930):1749-61. PMID:24480518
30. Kakumu S, Okumura A, Ishikawa T, Yano M, Enomoto A, Nishimura $\mathrm{H}$, et al. Serum levels of IL-10, IL-15 and soluble tumour necrosis factor-alpha (TNF-alpha) receptors in type C chronic liver disease. Clin Exp Immunol. 1997 Sep;109(3):458-63. PMID:9328122

31. Mohamed SO, Ahmed MA, Amal AM, Wesam A. I. Serum levels of interleukin-6 and interleukin-10 as biomarkers for hepatocellular carcinoma in Egyptian patients. ISRN Hepatology. 2013; Article ID 412317. http://dx.doi. org/10.1155/2013/412317

32. Matsuguchi T, Okamura S, Kawasaki C, Niho Y. Production of interleukin 6 from human liver cell lines: production of interleukin 6 is not concurrent with the production of alpha-fetoprotein. Cancer Res. 1990 Dec 1;50(23):7457-9. PMID:1701344

33. Ko $S$, Nakajima $Y$, Kanehiro $H$, Hisanaga $M$, Aomatsu $Y$, Kin $\mathrm{T}$, et al. Significant influence of accompanying chronic hepatitis status on recurrence of hepatocellular carcinoma after hepatectomy. Result of multivariate analysis. Ann Surg. 1996 Nov;224(5):591-5. PMID:8916872

34. Chiodoni C, lezzi M, Guiducci C, Sangaletti S, Alessandrini I, Ratti C, et al. Triggering CD40 on endothelial cells contributes to tumor growth. J Exp Med. 2006 Oct 30;203(11):2441-50. PMID:17043144 